\title{
Efek Pemberian Ekstrak Daun Pegagan (Centella Asiatica) terhadap Penyembuhan Luka Sayat pada Tikus Putih Jantan (Rattus Norvegicus) Galur Wistar
}

\author{
I Made Subhawa Harsa \\ Bagian Ilmu Faal Fakultas Kedokteran Universitas Wijaya Kusuma Surabaya. \\ e-mail: madesubhawah@gmail.com
}

\begin{abstract}
Abstrak
Luka merupakan hilang atau rusaknya sebagian jaringan tubuh. Salah satu cara yang telah digunakan masyarakat dalam membantu proses penyembuhan luka adalah penggunaan tanaman obat, seperti pegagan (Centella asiatica). Pegagan (Centella asiatica) merupakan tanaman yang terdapat di seluruh Indonesia yang berfungsi sebagai revitalisasi sel, yaitu mempercepat penyembuhan luka, luka bakar, borok kulit dan pencegahan keloid. Penelitian ini bertujuan untuk mengetahui efek pemberian ekstrak daun pega-gan (Centella asiatica) terhadap penyembuhan luka sayat pada tikus putih jantan (Rattus norvegicus) galur wistar. Penelitian ini merupakan penelitian eksperimental murni dengan menggunakan rancangan penelitian the randomized posttest only control group design dengan besar sampel adalah 30 ekor tikus putih jantan (Rattus norvegicus) galur wistar yang dibagi dalam 3 kelompok, yaitu $\mathrm{K} 1, \mathrm{~K} 2$, dan K3. Pada setiap kelompok, dibuat luka sayat dengan panjang $\pm 2 \mathrm{~cm}$ dan kedalaman $\pm 2 \mathrm{~mm}$ di bagian punggung. Luka pada kelompok kontrol negatif (K1), tidak diberi apa-apa; pada kelompok kontrol positif (K2), diberi povidone iodine 10\%; dan pada kelompok perlakuan (K3), diberi ekstrak daun pegagan secara topikal dengan dosis $37,5 \mathrm{mg} / 150$ grBB. Penelitian dilakukan selama 10 hari. Selanjutnya, dilakukan pengamatan dan penilaian luka. Kemudian hasil diolah dengan menggunakan uji One Way ANOVA. Hasil penelitian penyembuhan luka sayat pada tikus putih jantan (Rattus norvegicus) galur wistar menunjukkan bahwa ada perbedaan bermakna antara kelompok kontrol negatif (K1), kontrol positif (K2), dan perlakuan (K3) pada uji One Way ANOVA dengan signifikansi $p$-value 0,027 ( $<<0,05)$. Pada uji Post-Hoc LSD juga menunjukkan ada perbedaan yang signifikan antara kelompok K1 dengan K3 dan kelompok K2 dengan K3 dengan signifikansi $p$-value masing-masing adalah 0,011 dan 0,038 ( $p$ $<0,05$ ). Dari hasil penelitian ini, dapat disimpulkan bahwa pemberian ekstrak daun pegagan (Centella asiatica) berpengaruh dalam mempercepat proses penyembuhan luka sayat pada tikus putih jantan (Rattus norvegicus) galur wistar.
\end{abstract}

Kata Kunci: Ekstrak Daun Pegagan, Luka Sayat, Tikus Putih Jantan (Rattus norvegicus) Galur Wistar.

\section{The Effect Of Giving Gotu Kola Leaf Extract (Centella Asiatica) Against to The Healing of The Wound Incision on Male White Rats (Rattus Norvegicus) Wistar Strain}

\begin{abstract}
Wound refers to partly damage or loss of body tissue. One way that has been used by the people in helping the process of wound healing is the use of medicinal plants, such as gotu kola
\end{abstract}


(Centella asiatica). Gotu kola (Centella asiatica) is kind of plant that found almost in all territories of Indonesia which functions as a cell revitalizing substance which quickens wound healing those are burnt, skin ulcer and to prevent keloid. This study is aimed to know the effect of giving gotu kola leaf extract (Centella Asiatica) against to the healing of the wound incision on male white rats (Rattus Norvegicus) wistar strain. This study is a pure experimental research using the randomized post test only control group design with the subjects are 30 male white rats (Rattus norvegicus) wistar strain that were divided into 3 groups, namely K1, K2, and $K 3$. The incision wound were made on the back of all white rat in each group with a length of \pm 2 $\mathrm{cm}$ and a depth of $\pm 2 \mathrm{~mm}$. The wound in the negative control group (K1) was not given any substance; in the positive control group (K2) was given povidone iodine 10\%; and in the treatment group (K3) was given gotu kola leaf extract at a dose of 37,5 mg/150 grBB. The study was done for 10 days. Furthermore, wound observation and monitoring is held. Then the results were processed by using One Way ANOVA. The result study of wound incision healing on male white rats (Rattus norvegicus) wistar strain shows that there is significant difference among the negative control group (K1), the positive control group (K2), and the treatment group (K3) on One Way ANOVA test which significant $p$-value are $0,027(p<0.05)$. The result of Post-Hoc LSD test also shows a significant differences among the $K 1$ and $K 3$ groups, and $K 2$ and $K 3$ groups which significant $p$-values are 0,011 and 0,038 $(p<0,05)$. From these results, it can be concluded that gotu kola leaf extract (Centella asiatica) effective on quickens wound healing of the wound incision on male white rats (Rattus norvegicus) wistar strain.

Keywords: Gotu kola leaf extract, wound incision, male white rats (Rattus norvegicus) wistar strain

\section{PENDAHULUAN}

Luka merupakan hilang atau rusaknya sebagian jaringan tubuh yang dapat disebabkan oleh trauma benda tajam atau tumpul, perubahan suhu, zat kimia, ledakan, sengatan listrik, atau gigitan hewan (Hasibuan et al, 2013). Saat ini, banyak cara yang telah digunakan masyarakat dalam membantu proses penyembuhan luka. Salah satu cara yang sudah banyak dikenal dan sering digunakan adalah penggunaan antiseptik. Antiseptik memiliki kelebihan, yaitu sebagai antimikroba yang dapat mematikan pertumbuhan bakteri. Disamping memiliki kelebihan, antiseptik juga memiliki kekurangan, yaitu dapat membunuh leukosit yang merupakan sel darah putih yang dapat membunuh bakteri patogen dan jaringan fibroblas yang membentuk jaringan kulit baru. Selain itu, antiseptik juga dapat menimbulkan perubahan pada warna kulit; menimbulkan scar atau jaringan parut yang akan menimbulkan bekas di kulit; dan pada pasien yang sensitif, antiseptik juga dapat menyebabkan iritasi (Burfeind, 2007; Setyoadi dan Sartika, 2010). Berdasarkan efek samping dari penggunaan antiseptik tersebut, masyarakat mulai menggunakan cara lain untuk membantu proses 
penyembuhan luka, yaitu dengan memanfaatkan pengobatan tradisional.

Salah satu tanaman yang dapat dimanfaatkan sebagai tanaman obat dalam menyembuhkan luka adalah pegagan (Centella asiatica). Pegagan merupakan tanaman yang terdapat di seluruh Indonesia yang tumbuh di tanah yang agak lembap dan cukup mendapat sinar matahari, seperti di padang rumput, sawah, pinggir selokan, dan sebagainya (Rampisela, 2010). Salah satu fungsi pegagan adalah sebagai revitalisasi sel, yaitu mempercepat penyembuhan luka, luka bakar, borok kulit, pencegahan keloid, dan bekas luka hipertropi (Permadi, 2008). Pegagan mengandung beberapa senyawa saponin, termasuk asiaticoside, asam asiatat, dan madecassoside yang memacu produksi kolagen I, thankunside, isothankunside, brahmoside, brahmic acid, madasiatic acid, meso-inosetol, centellose, carotenoids, garam kalium, natrium, kalsium, besi, fosfor, vellarine, tannin, mucilago, resin, pektin, gula, vitamin $\mathrm{B}$, sedikit vitamin $C$, minyak atsitri, kalsium oksalat, dan amygdalin. Pegagan bersifat sebagai anti-infeksi, antilepra, antisifilis, dan revitalisasi sel kulit. Diduga glikosida triterpenoida yang disebut asiaticoside merupakan antilepra dan penyembuh luka (Winarto dan Surbakti, 2005; Permadi, 2008).
Tujuan penelitian ini adalah untuk mengetahui efek pemberian ekstrak daun pegagan (Centella asiatica) terhadap penyembuhan luka sayat pada tikus putih jantan (Rattus norvegicus) galur wistar.

\section{METODE}

Penelitian ini merupakan penelitian eksperimental murni dengan menggunakan rancangan penelitian the randomized posttest only control group design. Populasi dari penelitian ini adalah tikus putih jantan (Rattus norvegicus) galur wistar yang berusia 2-3 bulan dengan berat badan 150200 gram dan dalam keadaan sehat (tidak mengalami kelainan anatomis atau cacat) dengan sampel 30 ekor tikus putih jantan (Rattus norvegicus) galur wistar yang dibagi menjadi tiga kelompok yaitu kelompok kontrol negatif (K1), kelompok kontrol positif (K2), dan kelompok perlakuan (K3). Pada setiap kelompok, dibuat luka sayat dengan panjang $\pm 2 \mathrm{~cm}$ dan kedalaman \pm 2 $\mathrm{mm}$ di bagian punggung. Luka pada kelompok kontrol negatif (K1), tidak diberi apa-apa; pada kelompok kontrol positif (K2), diberi povidone iodine 10\%; dan pada kelompok perlakuan (K3), diberi serbuk kering ekstrak daun pegagan dengan cara ditaburi pada luka sayat dengan dosis 37,5 mg/150 grBB. Penelitian dilakukan selama 10 hari. Selanjutnya, dilakukan pengamatan dan penilaian luka secara 
ISSN 1978-2071 (Print); ISSN 2580-5967 (Online) Jurnal IImiah Kedokteran Wijaya Kusuma 9(1): 21-27, Maret 2020

makroskopis dengan melihat beberapa kriteria kesembuhan luka, yaitu kondisi kulit kering, warna luka seperti kulit normal, tidak ada tanda-tanda infeksi (pus/eksudat), tidak terdapat jaringan nekrotik, tidak terdapat eritema, dan tidak terdapat edema. Dengan kriteria skoring yaitu 0 = Bila tidak ada kriteria yang terpenuhi; 1 = Bila 1-2 kriteria yang terpenuhi; 2 = Bila $3-5$ kriteria yang terpenuhi; $3=$ Bila semua kriteria terpenuhi.

\section{HASIL}

Tabel 1. Hasil Data Deskriptif Ketiga Kelompok

\begin{tabular}{cccc}
\hline Kelompok & N & Mean & Std. Deviation \\
\hline K1 & 9 & 2.1111 & .33333 \\
K2 & 9 & 2.2222 & .44096 \\
K3 & 9 & 2.6667 & .50000
\end{tabular}

Sumber data: Hasil penelitian 2019 Berdasarkan tabel di atas dapat diketahui bahwa kelompok 3 mempunyai rata-rata penyembuhan luka yang paling besar, yaitu sebesar 2,67. Disusul dengan kelompok 2 sebesar 2,22 dan rata-rata penyembuhan luka terendah ada pada kelompok 1, yaitu sebesar 2,11.

Tabel 2. Hasil Uji One Way ANOVA antara Ketiga Kelompok

\begin{tabular}{lcccc}
\hline & $\begin{array}{c}\text { Jumlah } \\
\text { Kuadrat }\end{array}$ & Df & F & Sig. \\
\hline Antar & 1.556 & 2 & 4.200 & .027 \\
kelompok & & & & \\
Dalam & 4.444 & 2 & & \\
Kelompok & & 4 & & \\
Total & 6.000 & 2 & & \\
& & 6 & & \\
\hline
\end{tabular}

Sumber data: Hasil penelitian 2019
Berdasarkan hasil di atas, signifikansi $p$-value adalah $0,027(p<0,05)$ sehingga $\mathrm{Ho}$ ditolak, maka dapat disimpulkan ada perbedaan bermakna antara kelompok kontrol negatif (K1), kelompok kontrol positif (K2), dan kelompok perlakuan (K3).

Tabel 3. Hasil Uji Post-Hoc LSD antara Ketiga Kelompok

\begin{tabular}{|c|c|c|c|}
\hline \multicolumn{2}{|c|}{ Kelompok } & \multirow{2}{*}{$\begin{array}{l}\text { Sig. } \\
0.589\end{array}$} & \multirow{2}{*}{$\begin{array}{l}\text { Keterangan } \\
\text { Tidak signifikan }\end{array}$} \\
\hline K1 & $\mathrm{K} 2$ & & \\
\hline & K3 & 0.011 & Signifikan \\
\hline K2 & K3 & 0.038 & Signifikan \\
\hline
\end{tabular}

Sumber data: Hasil penelitian 2019

Pada uji Post-Hoc LSD menunjukkan bahwa ada perbedaan yang signifikan antara kelompok K1 dengan K3 dan kelompok K2 dengan K3, dimana diketahui bahwa nilai p masing-masing adalah 0,011 dan 0,038 ( $p<0,05)$. Sedangkan antara kelompok K1 dengan K2 menunjukkan tidak ada perbedaan yang signifikan, terbukti dengan nilai $p=0,589(p>0,05)$.

\section{PEMBAHASAN}

Hasil penelitian pada tabel 1 dan 2 menunjukkan bahwa pemberian ekstrak daun pegagan (Centella asiatica) berpengaruh dalam mempercepat proses penyembuhan luka sayat pada tikus putih jantan (Rattus norvegicus) galur wistar. Tikus yang diberi ekstrak daun pegagan mempunyai penyembuhan luka yang lebih baik dari pada dua kelompok yang lain terbukti dari hasil pengamatan luka sayat pada kelompok K3 didapatkan rata-rata penyembuhan luka yang paling besar yang 
ditandai dengan adanya beberapa kondisi yaitu kulit kering, warna luka seperti kulit normal, tidak ada tanda-tanda infeksi (pus/eksudat), tidak terdapat jaringan nekrotik, tidak terdapat eritema, dan tidak terdapat edema.

Hal ini disebabkan karena kandungan bahan aktif yang ditemukan dalam pegagan (Centella asiatica) meliputi: triterpenoid saponin, triterpenoid genin, minyak esensial, flavonoid, dan bahan aktif lainnya. Bahan aktif triterpenoid saponin dapat meningkatkan aktivasi makrofag yang menyebabkan peningkatan fagositosis dan sekresi interleukin yang akan memacu sel B untuk menghasilkan antibodi (Besung, 2009)

Pegagan mampu memacu proliferasi sel fibroblas yang berperan besar pada penyembuhan luka karena kemampuannya dalam memproduksi substansi dasar pembentuk serat kolagen (Redaksi Trubus, 2010). Asiatic acid mampu menstimulasi sintesis kolagen, sementara madecassoside mampu meningkatkan sekresi kolagen tipe III dan memiliki efek anti-inflamasi (Zheng dan Qin, 2007).

Asiaticoside berfungsi untuk meningkatkan perbaikan dan penguatan sel-sel kulit, stimulasi pertumbuhan kuku, rambut dan jaringan ikat (Setyoadi dan Sartika, 2010). Penelitian lebih lanjut menunjukkan bahwa asiaticoside merangsang sintesis kolagen tipe I melalui aktivasi TGF- $\beta$ receptor I kinaseindependent Smad pathway, yang menjadi dasar untuk pemahaman molekul bioaktivitas Centella pada penyembuhan luka. Sementara itu, madecassoside mampu meningkatkan sekresi kolagen III secara signifikan (Zheng dan Qin, 2007).

Beberapa saponin bekerja sebagai antimikroba (sumber anti-bakteri dan anti virus) meningkatkan sistem kekebalan tubuh; meningkatkan vitalitas; kadar gula dalam darah; mengurangi penggumpalan darah; dan saponin juga dapat memacu pertumbuhan kolagen dalam proses penyembuhan luka (tahap awal perbaikan jaringan), yaitu dengan menghambat produksi jaringan luka yang berlebihan; serta memiliki efek menghilangkan rasa sakit dan merangsang pembentukan sel-sel baru (Igbinosa et al, 2009; Setyoadi dan Sartika, 2010).

Selain saponin flavonoid juga berperan dalam proses penyembuhan luka. Banyak penelitian telah terbukti bahwa molekul flavonoid yang berbeda menunjukkan aktivitas anti-inflamasi. Dengan demikian, aktivitas anti-inflamasi flavonols (quercetin, rutin, dan morin) dan flavanones (hesperetin dan hesperidin) telah diteliti pada inflamasi akut dan kronis hewan coba. Beberapa flavonoid dan polifenol tanaman lainnya memiliki 
kemampuan untuk menghambat jalur siklooksigenase (COX-2) dan lipoksigenase (Lafuente et al, 2009).

Menurut Grzanna, Lindmark dan Frondoza (2005), "Salah satu jenis flavonoid, yaitu quercetin dapat menghambat jalur siklooksigenase dan lipoksigenase pada metabolisme asam arakidonat sehingga menyebabkan terganggunya sintesis prostaglandin dan leukotrien." Jalur siklooksigenase dan lipoksigenase yang terhambat, menyebabkan produksi prostaglandin dan leukotrien berkurang. Berkurangnya prostaglandin sebagai mediator inflamasi dapat menyebabkan nyeri dan pembengkakan berkurang, serta mengurangi terjadinya vasodilatasi pembuluh darah dalam aliran darah lokal sehingga migrasi sel radang akan menurun (Balqis, 2014).

Flavonoid juga menunjukkan efek pada proses sekresi sel-sel inflamasi. Beberapa flavonoid seperti luteolin, kaempferol, apigenin, atau quercetin telah dilaporkan sebagai penghambat $\beta$ glucuronidase dan pelepasan lisosim dari neutrofil. Flavonoid ini secara signifikan menghambat pelepasan asam arakidonat dari membran. Banyak penelitian telah menunjukkan bahwa molekul flavonoid yang berbeda memodulasi aktivitas asam arakidonat (AA) yang memetabolisme enzim seperti fosfolipase $A_{2} \quad\left(P L A_{2}\right)$; siklooksigenase (COX) dan lipoksigenase (LOX); dan enzim penghasil nitric oxide (NO), yaitu nitric oxide synthase (NOS). Penghambatan enzim-enzim ini oleh flavonoid, mengurangi pembentukan asam arakidonat, prostaglandin, leukotrien, dan NO, yang merupakan mediator inflamasi yang penting (Lafuente et al., 2009).

\section{KESIMPULAN}

Hasil penelitian menunjukkan bahwa pemberian ekstrak daun pegagan (Centella asiatica) dapat mempercepat proses penyembuhan luka sayat pada tikus putih jantan (Rattus norvegicus) galur wistar dibandingkan dengan pemberian $\mathrm{Nacl}$ 0,9\% dan povidone iodine.

\section{DAFTAR PUSTAKA}

Balqis U, Masyitha D, dan Febrina F, 2014. Proses Penyembuhan Luka Bakar dengan Gerusan Daun Kedondong (Spondias dulcis F.) dan Vaselin pada Tikus Putih (Rattus norvegicus) secara Histopatologis. Jurnal Medika Veterinaria 8(1): 1-14.

Besung INK, 2009. Pegagan (Centella asiatica) sebagai alternatif pencegahan penyakit infeksi pada ternak. Buletin Veteriner Udayana. 1(2): 61-67. 
Burfeind DB, 2007. Dermatology nursing.

Vol 19. Pitman: Anthony J. Janetti, Inc. p. 93.

Hasibuan LY, Soedjana H, Bisono, 2013. Luka. Dalam Buku Ajar IImu Bedah Sjamsuhidajat-de Jong, Edisi 3. Editor R. Sjamsuhidajat, Warko Karnadihardja, Theddeus O. H. Prasetyono, dan Reno Rudiman. Penerbit Buku Kedokteran EGC. Jakarta. Halaman 95-120.

Igbinosa OO, Igbinosa EO, Aiyegoro OA, 2009. Antimicrobial activity and phytochemical screening of stem bark extracts from Jatropha curcas (Linn). African Journal of Pharmacy and Pharmacology 3(2): 058-062.

Lafuente AG, Guillamon E, Villares A, Rostagno M A, Martinez JA, 2009. Flavonoids as anti-inflammatory agents: implications in cancer and cardiovascular disease. Inflammation Research 58(9): 537-552.

Permadi A, 2008. Membuat Kebun Tanaman Obat. Jakarta: Pustaka
Bunda (Grup Puspa Swara), Anggota Ikapi. Halaman 45-46.

Rampisela, Johanis, 2010. Hidup Sehat: Daun Kaki Kuda atau Pegagan. http://forum.upi.edu/v3/index.ph p?action $=$ printpage $;$ topic $=12089$. $O$ (diakses pada tanggal 18 Mei 2014, pukul 13.14 WIB).

Redaksi Trubus, 2010. Herbal Indonesi Berkhasiat: Bukti Ilmiah dan Cara Racik. Halaman 393-396.

Setyoadi, Sartika, Dina D, 2010. Efek Lumatan Daun Dewa (Gynura segetum) dalam Memperpendek Waktu Penyembuhan Luka Bersih pada Tikus Putih. Jurnal Keperawatan Soedirman (The Soedirman Journal of Nursing) 5(3): 127-135.

Winarto WP, Surbakti M, 2005. Khasiat \& Manfaat Pegagan: Tanaman Penambah Daya Ingat. Cetakan 4. Jakarta: Agromedia Pustaka.

Zheng CJ, Qin LP, 2007. Chemical Components of Centella asiatica and their Bioactivities. $J$ of Chinese Integrative Medicine 5(3): 348-351. 